\title{
Random Peptide Synthesis
}

National Cancer Institute

\section{Source}

National Cancer Institute. Random Peptide Synthesis. NCI Thesaurus. Code C19575.

Generation of peptide libraries by random incorporation of all 20 amino acids. 